\title{
Review Article \\ CLINICAL DIAGNOSTICS OF HEPATOPATHIES IN SMALL MAMMALS: EVALUATION OF IMPORTANCE OF INDIVIDUAL METHODS
}

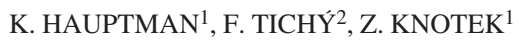 \\ ${ }^{1}$ Small Animal Clinic, ${ }^{2}$ Department of Anatomy, Histology and Embryology, Faculty of Veterinary Medicine, \\ University of Veterinary and Pharmaceutical Sciences, Brno, Czech Republic \\ Received December 14, 2000 \\ Accepted May 28, 2001 \\ Abstract \\ Hauptman, K., F. Tichý, Z. Knotek: Clinical Diagnostics of Hepatopathies in Small \\ Mammals: Evaluation of Importance of Individual Methods. Acta Vet. Brno 2001, 70: 297-311. \\ Until recently the possibilities of intravital diagnosis of liver function affection in small \\ mammals have only been utilised to a minimum extent. The necessity of early hepatic disease \\ diagnostics in these patients is highly topical. The presented paper summarises diagnostic \\ procedures and will show the evaluation of their practical use in small mammals. Anamnestic data \\ evaluation, palpation of the liver and collection of fluid from the abdominal cavity for the purpose \\ of laboratory examination play an irreplaceable role in the diagnostics of liver diseases in small \\ mammals. Biochemical blood indices analysis includes enzymes indicating hepatocellular damage \\ (ALT, AST, LDH), cholestasis or enzymatic activity alteration (ALP, GGT), values monitoring \\ the liver synthesis (albumin, glucose, urea, coagulation factors, bilirubin, bile acids, ammonium). \\ Cytology and histology of biopsy specimens make it possible to evaluate the liver state precisely. \\ In small mammals the size of a rabbit, ferret, adult guinea pig or rat utilisable methods for the liver \\ biopsy include: fine needle aspiration biopsy, percutaneous biopsy, biopsy under the guidance of \\ ultrasonography, biopsy under endoscopic or otoscopic guidance and biopsy during exploratory \\ laparotomy. In patients the size of a hamster, Djungarian hamster or mouse the indication of these \\ methods are questionable they can casuse serious hazards to the animals life. In spite of this, \\ modifications of liver biopsy sampling are of conclusive importance in the diagnostics of \\ hepathopathies in small mammals. In minute small mammals we can use a modification of the \\ percutaneous biopsy using a key-hole technique and biopsy during laparotomy.
}

Rabbit, ferret, rodents, liver biopsy, ascites, endoscopy

Veterinary medicine deals with questions of the diagnostics of hepatopathies traditionally in large farm animals as well as small domestic ones (House 1992; Carlton and McGavin 1995). It is also the group of small mammals which are relatively frequently affected by various forms of liver disease (Meredith and Rayment 2000). There are primary liver parenchyma affections as well as secondary hepatopathies caused by metabolic disorders, enteropathies, intoxication, nephropathies or some other systemic changes in these animals. Differentiation of primary and secondary liver parenchyma affections is very difficult and in many cases practically impossible (Dial 1995). The diagnostics of liver damage in small mammals is much more complicated than in dogs and cats. Difficulty in handling the patients is one of the reasons. They are often semi-wild and the examining surgeon is in danger of being hurt. That is why thorough examination most of small mammal patients require sedation which, however, may be an exacerbating factor. The size of the patient presents another limitation due to complications of both the basic clinical examination and the use of some diagnostic imaging methods (radiographic and ultrasound). The body weight and size also influence the volume of blood samples (it is possible to collect blood volume representing $0.5 \%$ of the body weight without major problems). It is particularly necessary to consider the financial aspect, because the cost of

Address for correspondence:

MVDr. K. Hauptmann

Small Animal Clinic,Faculty of Veterinary Medicine

Cherinary and Pharmaceutical Sciences Brno

Palackého 1-3, 61242 Brno, Czech Republic
Phone: +420541562382

Fax: +420541562382

http://www.vfu.cz/acta-vet/actavet.htm 
the already mentioned methods often exceeds many times the price of the patient. Commercial large-scale fur-animal and professional laboratory animal farms base their diagnostics of hepatopathies mainly on post-mortem pathoanatomical examination of animals that died or were killed (Jelínek et al. 1993; Fox 1998). The microscopic structure and functions of liver in small mammals are to a greater extent similar to those in other vertebrates. High rates of metabolism and limited energy reserves (unlike in dogs and cats) call for active participation of the liver in the redistribution of energetic sources, especially during reproduction. Alterations of liver functions are reflected in the production of antibodies and influence the results of the electrophoretic examination of blood sera of patients (Sevelius and Andersson 1995; Knotek 1996). A rise in the antibody production in these cases results in higher proportion of $\gamma$-globulins. Higher levels of $\gamma$-globulins in the blood serum are detected in animals suffering from necrotic processes, while lower concentrations of this fraction accompany states of malabsorption, malnutrition, and advanced liver disease (Center 1993).

Possibilities of intravital diagnostics of liver function alterations in small mammals have until recently been used to a minimum extent in comparation to dogs or cats. The necessity of early disease diagnostics, including liver function alterations, in small mammals is, nevertheless, more than topical. The reason are in the endeavour to make an exact diagnosis, objective prognosis and, when possible, start a regimen of specific and non-specific therapy (Egen and Ernst 1995; Meredith and Rayment 2000). The possibility to monitor liver state using cytology and histology of liver biopsy specimens seems very practical (Day 2000).

The aim of this paper is to briefly bring together current possibilities of intravital diagnostics of hepathopathies of small mammals and evaluate their practical use in these patients.

\section{History}

Anamnestic data evaluation plays an important role in the diagnostics of liver diseases in small mammals. It frequently warns the veterinary surgeon of a possibility of liver disease being in progress in the patient (Table 1). Owners notice inappetence lasting several days, lethargy and wasting (Giebler 1995; Rothuizen and Meyer 2000). In other cases discovered errors in nutrition leading to obesity in the patient. In mammals suffering from chronic liver function damage it is to be expected that considerably higher levels of products of protein metabolism exceeding the filtration capacity of kidneys. In mammals suffering from chronic alteration of liver functions it is supposed, due to the overall catabolism, a marked rise in products of protein metabolism that exceeds the filtration capacity of kidneys. Hepathopathies in such patients are therefore often accompanied by nephropathies leading to chronic renal failure (Rothuizen and Meyer 2000). Disruption of liver and kidney functions may be manifested in these patients with signs of diarrhoea, polyuria and polydipsia (Giebler 1995; Rothuizen and Meyer 2000).

Table 1

Selected anamnestic data and clinical signs associated with the liver damage in small mammals

\begin{tabular}{|c|c|}
\hline Anamnestic data mentioned by the owner & Clinical signs \\
\hline Anorexia & Icterus \\
Lethargy, depression, apathy & Polyuria/Polydipsia \\
Progressive wasting & Ascites, abdominal distension \\
Vomiting, diarrhoea & Coagulopathies, tendency to bleeding \\
Changes to the abdominal configuration & Neurological signs, seizures, collapse \\
\hline
\end{tabular}




\section{Clinical examination}

Insufficient liver functions accompanied by clinical signs are evident in animals only when more than 70-80\% of liver tissue gets damaged (Klimeš 1997). Clinical signs of hepathopathies are frequently blurred by symptoms of damage to other organ systems. But damage to other organ systems also may lead to liver tissue affection secondarily (Dial 1995). Long-lasting anorexia, for example, caused by maldigestion (due to chronic diarrhoea, foreign body presence, intestinal invagination, pancreatic insufficiency) leads to changes in the metabolism of fats (Clarenburg 1992a; Center 1993; Egen and Ernst 1995; Gabris ch 1995). These processes then often result in liver steatosis (Yeager 1992). Serious enteritis cases enable bacteria to penetrate through the altered intestinal mucosa and as a sequel to this damage the liver tissue (Greene 1998). Systemic diseases such as the Tyzzer's disease, salmonellosis, listeriosis and toxoplasmosis damage the liver tissue as well (Jelínek 1992). It is therefore necessary, when examining patients with clinical signs of affection of other organ systems, to find out whether it is not a complicating factor to liver damage.

Thorough clinical examination in some patients suffering from considerable liver damage may reveal marked changes of mucous membranes, i.e., petechiae due to coagulopathies or icterus (Kerwin 1995; Rothuizen and Meyer 2000). But in animals such as ferrets and rabbits these signs are seen only rarely (Hoefer 1992; Meredith and Rayment 2000). As far as other symptoms associated with liver damage are concerned, there may be found neurological deficits (stupor, circling, head pressing) and later seizures and coma (Bunch 1998a). The patient's respiration is impaired by the increased size of the liver (hepatomegaly) as well as the effusion in the thoracic cavity. In these cases a patient may suffering from a progressive dyspnea. There also may be abdominal distension caused by ascites, liver enlargement or liver masses. It is of practical diagnostic importance in such a patient to perform abdominal palpation and collection of the fluid from the abdominal cavity for the purpose of further laboratory analysis.

In the dog and cat it is possible to use a combination of diagnostic imaging methods for the purpose of intravital liver size and shape evaluation. These methods are used only to a limited extent in small mammals.

\section{Radiography}

A combination of laterolateral and ventrodorsal projections is suitable for liver imaging. The size, the position and the density characteristics of the liver are evaluated. As a general rule, the liver image considerably beyond the rib arch may be considered to be liver enlargement (Popesko et al. 1990a, 1990b). It is, however, necessary to know that in all small mammals the liver exceeds the lower margin of the rib arch physiologically (Popesko et al. 1990a, Popesko et al. 1990b; Brown 1992).

Evaluating some hepatomegaly in a more exact way, it is necessary to examine the axis of the stomach in relation to the axis of the body, which changes in such cases. Radiographs reveal also masses that are associated or only adjacent to the liver (tumours, abscesses), as well as position changes due to a hernia and a torsion of liver lobes (Miles 1997). Radiography in small mammals may confirm the presence of ascitic fluid in the abdominal cavity - manifested as a loss of clarity and detail of the abdominal cavity (Meredith and Rayment 2000). In our opinion and practice this examination requires sedation of the patient for a proper positioning and a quality radiograph taking.

Contrast angiography may be used to visualise radiologically the vascular system and 
demonstrate vascular shunts (Center 1993; Leveille-Webster 2000). Because of its exacting character it is not commonly used in small mammals.

\section{Ultrasonography}

It is a non-invasive technique that makes it possible to characterise the liver parenchyma structure, liver size, and also masses or focal changes such as abscesses, tumours and cysts (Miles 1997).

Using ultrasonography it is possible to localise lesions larger than $0.5 \mathrm{~cm}$ in size (Center 1998). This technique may be used to obtain biopsy specimens from the liver tissue and masses adjacent to the liver. Its practical use, however, is considerably limited by the size of the patient (the probe is quite often of the same size as the patient).

\section{Doppler ultrasonography}

Doppler ultrasonography is a non-invasive technique for the evaluation of tissue perfusion. In comparison with other organs there are two kinds of blood circulation in the liver. The portal venous system has low blood pressure in vessels without strong pulsation. In the arterial system on the other hand, there is a marked stronger pulsatile blood flow because of higher blood pressure in vessels. In patients suffering from liver cirrhosis the intrahepatic resistance of vessels increases up to five times and, proportionately to it, the portal system blood pressure rise leads to portocaval shunt formation. It is possible to examine the hepatic arterial blood flow using either transcutaneous or intravascular Doppler ultrasonography techniques (Hubner et al. 2000). These methods, however, are not commonly employed. The minute size of patients poses also some technical limitation.

\section{Computer tomography, magnetic resonance, scintigraphy}

Computer tomography makes it possible to generate images of structures and organs only slightly differing from their surroundings. The degree of resolution of structures and imaging of pathologic changes further enhances with additional use of contrast media through i.v. injection. Computer tomography is reliable in demonstrating focal hepatic changes (cysts, tumours, abscesses). In diffuse changes, its reliability is lower (Kelner 1999a). The method, however, is beyond the possibilities of a common veterinary practice. Considering the need for the i.v. administration of contrast media, it is difficult to use in small mammals.

The method of magnetic resonance is valuable for the examination of soft tissues and vascular changes (Kelner 1999b). When examining the liver, this method can be supplemented by the administration of contrast media resulting in a complete biliary tract imaging (Angulo et al. 2000).

Scintigraphy is a method to examine the hepatobiliary system. It uses a ${ }^{99 \mathrm{~m}} \mathrm{Tc}$ marked derivative of iminodiacetate (Rothuizen et al. 1990) and identifies intra- or extra-hepatic obstructions, biliary atresia and other cholestatic diseases (Lofsted et al. 1988; Rothuizen and Meyer 1990; Boothe et al. 1992; Bunch 1998b).

\footnotetext{
Abdominocentesis

Characterising the ascitic fluid is an important step in the investigation to search for causes of liver function affection. Fluid aspiration through a puncture of the abdominal cavity (abdominocentesis) is an uncomplicated procedure without serious hazards for the patient. It is performed using a $20-22 \mathrm{G}$ needle inserted paramedially in the right cranial quadrant
} 
Table 2

Differential diagnosis of abdominal effusions (Anderson 1992; Lorenz and Cornelius 1992)

\begin{tabular}{|c|c|c|c|}
\hline & Exudate & Modified transudate & Transudate \\
\hline Colour, clarity & $\begin{array}{l}\text { Various colours, } \\
\text { turbid or opaque }\end{array}$ & Very often colourless & Mostly colourless and clear \\
\hline Proteins $(\mathrm{g} / \mathrm{l})$ & $>35$ & $0-50$ & $<25$ \\
\hline $\begin{array}{l}\text { Cell numbers } \\
\text { per } 1 \mathrm{~mm}^{3}\end{array}$ & $>20000$ & $1000-20000$ & $<1000$ \\
\hline Specific gravity & $>1.025$ & $1.010-1.025$ & $<1.016$ \\
\hline Kinds of cells & $\begin{array}{l}\text { Neutrophilic granulocytes, } \\
\text { macrophages, there may be } \\
\text { degenerated cells }\end{array}$ & $\begin{array}{c}\text { Mononuclear leukocytes, } \\
\text { low percentage of } \\
\text { neutrophilic granulocytes }\end{array}$ & $\begin{array}{l}\text { Mononuclears, } \\
\text { mesothelial cells }\end{array}$ \\
\hline $\begin{array}{c}\text { Presence of } \\
\text { Bacteria }\end{array}$ & Variable & No & No \\
\hline \multirow{9}{*}{$\begin{array}{l}\text { Associated } \\
\text { processes }\end{array}$} & Sepsis & Cardiac failure & Hypoalbuminaemia \\
\hline & Ruptured abscesses & Cardiomyopathy & Hepatic insufficiency \\
\hline & Pancreatitis & Abdominal neoplasia & Diarrhoea \\
\hline & $\begin{array}{l}\text { Intraperitoneal drug } \\
\text { administration }\end{array}$ & $\begin{array}{c}\text { Obstruction of hepatic } \\
\text { vessels or vena cava caudalis }\end{array}$ & Fasting \\
\hline & $\begin{array}{l}\text { Bile, urine in the } \\
\text { peritoneal cavity }\end{array}$ & Lymphadenitis & $\begin{array}{l}\text { Persistent portal } \\
\text { hypertension }\end{array}$ \\
\hline & Thrombosis & & Liver cirrhosis \\
\hline & Torsion & & Chronic active hepatitis \\
\hline & Intussusception & & Chronic cholangiohepatitis \\
\hline & Trauma & & $\begin{array}{c}\text { Abdominal or hepatic } \\
\text { neoplasia with persistent } \\
\text { portal hypertension }\end{array}$ \\
\hline
\end{tabular}

(Anders on 1992). This procedure is employed in small mammals, too. Abdominocentesis is then followed by the collected fluid analysis - cell numbers and their kinds (inflammatory or neoplastic ones, etc.), protein concentration, specific gravity measurement, biochemical values (Perman 1989). The diagnostic efficacy is rather high. When the effusion in the abdominal cavity was formed by transudation (Table 2), it may supposed low albumin production by the liver parenchyma leading to low protein concentration in the blood serum and subsequent fluid passage from blood to body cavities (Rebar 1989a). Contrary to this bacterial peritonitis results in exudation (Table 3 ).

\section{Examination of faeces}

Coprology of the patient's faeces is aimed at the parasitological and bacteriological examination.

As far as parasites in small mammals are concerned, protozoans of the genus Eimeria which damage primarily the liver tissue in rabbits, e.g., Eimeria stiedae (Napier 1969; 
Table 3

Interpretation of changes in individual biochemical values of blood

\begin{tabular}{|c|c|c|c|}
\hline Values & Specificity & Increased levels & Decreased levels \\
\hline ALT & Medium & $\begin{array}{l}\text { Damage to the liver } \\
\text { parenchyma or cardiac muscle }\end{array}$ & Cause not known \\
\hline AST & Medium & $\begin{array}{c}\text { Damage to the liver parenchyma, } \\
\text { muscles anticonvulsant, } \\
\text { or corticosteroid drug therapy }\end{array}$ & Depletion of hepatocytes \\
\hline ALP & Low & $\begin{array}{l}\text { Cholestasis, affections } \\
\text { of kidney, bones, intestines }\end{array}$ & Cause not known \\
\hline GGT & Medium & $\begin{array}{l}\text { Damage to the liver } \\
\text { (hepatocellular damage or cholestasis), } \\
\text { kidney, pancreas }\end{array}$ & Cause not known \\
\hline Bile acids & High & Damage to the liver & Cause not known \\
\hline Bilirubin & Low & $\begin{array}{l}\text { Hemolysis, hepatocellular } \\
\text { damage, cholestasis }\end{array}$ & Cause not known \\
\hline Ammonium & High & $\begin{array}{c}\text { Disorders of portal circulation, } \\
\text { vascular shunts, loss } \\
\text { of hepatic parenchyma }\end{array}$ & Atrophy of the liver \\
\hline Total proteins & Low & Systemic diseases & Long-lasting diseases \\
\hline Glucose & Low & $\begin{array}{l}\text { Diabetes, hyperadrenocorticism, } \\
\text { drug-induced rise, laboratory error }\end{array}$ & Systemic diseases, fasting \\
\hline Urea & Low & $\begin{array}{l}\text { Diseases of the kidney, } \\
\text { chronic kidney disorders }\end{array}$ & $\begin{array}{c}\text { Inadequate diet, anorexia, } \\
\text { vascular shunts }\end{array}$ \\
\hline Cholesterol & Low & Biliary tract diseases & $\begin{array}{l}\text { Vascular shunts, } \\
\text { liver failure, cirrhosis }\end{array}$ \\
\hline
\end{tabular}

Schall 1995), are the most well-known group. Bacterial culture can prove helpful in diagnosing such diseases as salmonellosis, Tyzzer's disease, infections by Pseudomonas aeruginosa (Jelínek 1992; Donelly 1997; Greene 1998).

\section{Blood examination (biochemistry and cytology of blood elements)}

There are four basic groups of biochemical indices of the blood examination (Dial 1995):

1. Enzymes indicating hepatocellular damage (alanine aminotransferase ALT, aspartate aminotransferase AST, lactate dehydrogenase LDH), cholestasis or iatrogenic alteration of enzyme activities (alkaline phosphatase ALP, gamma glutamyl transferase GGT).

2. Indices associated with the liver output, conjugation and secretion (bilirubin and bile acids).

3. The so-called portal clearance (bile acids, ammonium).

4. Values monitoring the synthesis in the liver (albumin, glucose, urea, coagulation factors). 


\begin{abstract}
ALT and AST
These enzymes are localised mainly in the cytoplasm of hepatocytes (Sparkes and Gruffydd-Jones 1993). There are also isoenzymes of alanine aminotransferase (ALT) of mitochondrial origin and aspartate aminotransferase (AST) is present also in the heart muscle. The half-time of ALT in the rabbit is very short, i.e. only 5 hours, as compared to the dog in which it varies from 45 to 60 hours (Meredith and Ray ment 2000). The level of AST gets higher in cases of muscle tissue damage (Divers and Cooper 2000). Diffuse reversible processes, such as for example hypoxia, cause the rise in the enzyme level that is higher than in solitary lesions (hepatic abscesses). Final stages of liver diseases in mammals are due to the depletion of hepatocytes accompanied by levels of enzymes that are within limits or only slightly elevated (Center 1993; Sparkes and Gruffydd-Jones 1993). It is also necessary to keep in mind that long-lasting administration of anticonvulsant agents and corticosteroids results in the liver enzyme level rise (Dial 1995).
\end{abstract}

\title{
Cholestatic enzymes
}

Alkaline phosphatase (ALP) and $\gamma$-glutamyltransferase (GGT) are the two most commonly used enzymatic markers of cholestasis in the clinical practice of small animals (Sparkes and Gruffydd-Jones 1993). ALP, however, is also localised in bones, kidneys, intestines, placenta and leukocytes. The main part of the serum ALP activity is influenced by the damage to the liver and bones or a drug-induced rise. The half-time of ALP produced in the liver and bones in the cat amounts to 3 days. ALP produced in other organ systems is reduced to half within 6 minutes in dogs and 6 hours in cats (Center et al. 1992). The highest ALP activity is found on border membranes of bile ducts. High level of this enzyme indicates stasis in the bile ducts. The level rises in cases of bone and, in some authorsęopinion, other organ damage as well (Lorenz and Cornelius 1992).

GGT is produced in the liver, pancreas and kidney; the renal insoenzyme, however, is not commonly detectable in the blood. Serum GGT is mainly of hepatic origin and increased level indicates hepatocellular damage and stasis in bile ducts (Center 1993; Sparkes and Gruffydd-Jones 1993; Meredith and Rayment 2000). Acute liver damage in the blood serum of patients is manifested by the alteration of enzymes like AST, GGT, ALP, ALT and LDH. It is necessary to determine the level of creatine kinase (CK) and the concentration of bile acid to differentiate from myopathies.

\section{Indices associated with the liver output, conjugation, secretion and portal clearance}

There are no simple and reliable tests demonstrating the functionality of the liver parenchyma. Serum bilirubin and bile acids are not dependent only on the functionality of the liver parenchyma; their concentrations are related also to the alteration of the biliary tract (Center 1993; Sparkes and Gruffydd-Jones 1993). The determination of serum bile acid concentration is used as one of the liver function tests. The result depends on three components of the enterohepatic transport: passage of bile acids from the serum to hepatocytes, secretion of bile acids into the biliary system and re-circulation into the liver through the portal vascular system. Bile acids are produced in the liver, conjugated with taurine or glycine and secreted into the bile (Clarenburg 1992b). Bile acids play a role in the digestion and absorption of fat. The main bolus of bile acids is released in the duodenum and re-absorbed in the ileum. Only a small percentage of bile acids is excreted in faeces. Normal levels of bile acids are low and rise only after feeding. This effect is used in the diagnostics of hepatopathies when we measure their levels before and two hours after feeding (Center et al. 1985; Center and Baldwin et al. 1986). The determination of bile acids can be useful in animals having normal bilirubin levels in the serum (Dial 1995). 
Increased bile acid levels together with other characteristics of hepatic functions indicate liver parenchyma damage. The measurement of bile acid levels, however, is not useful in the differentiation of hepatocellular, vascular or cholestatic diseases.

Hyperbilirubinemia is caused by increased destruction of erythrocytes (pre-hepatic origin), hepatocellular dysfunction (damage to the liver) or cholestasis (post-hepatic origin). The aetiology of hyperbilirubinemia can be further differentiated by the determination of conjugated and unconjugated bilirubin levels, in small mammals, however, even these tests do not result in absolute diagnosis. In the ferret, for example, increased bilirubin level is not reliably for signified liver damage and jaundice is found only occasionally (Hoefer 1992).

The concentration of serum ammonia in the blood is a very reliable marker of hepatic functions (Sparkes and Gruffydd-Jones 1993). The level of ammonium in the serum is determined by the absorption from the small intestine where it is formed by protein breakdown. It is mainly absorbed and through the portal system transported to the hepatocytes, metabolised to urea and then excreted by the kidney (Leveille-Webster 2000). Disorders in the portal circulation, intra- or extra-hepatic shunts as well as functional changes of liver parenchyma result in the rise of the ammonium in the blood serum and, in its final effect, neurological signs (Center 1993; Bunch 1998a). As far as the methods are concerned, it is crucial for the ammonium measurement that the concentration be determined within 15 to 30 minutes after sampling. Heparin is used for the blood collection, the sample is cooled immediately and centrifuged for the purpose of separation of erythrocytes (Dial 1995).

\section{Indices monitoring the synthesis in the liver}

The liver is the primary source of many serum components: albumin, glucose, urea, cholesterol and the majority of coagulation factors. Their concentrations in the blood serum decrease only when the liver gets seriously damaged (Dial 1995). The glucose level is usually influenced by serious liver damage and other systemic disorders. It is only of orientation importance as an indicator of liver affection. Hypoproteinemia in the liver disease is associated with decreased production of albumin. Even this value is of orientation importance because it indicate only acute and chronic diseases. Chronic diseases result in hypoalbuminemia. Concurrent blood loss with hemostasis can, nevertheless, result in hypoalbuminemia even in cases of acute liver failure. In chronic inflammation cases, however, there are levelled concentrations of proteins due to hypergammaglobulinemia (Dial 1995). Levels of urea in the blood serum can be influenced by the functionality of liver parenchyma as well as the intake of proteins in the food. Anorectic animals and animals fed low-protein diet have a low urea blood level in comparation to reference values (Jergens 1997). Anorectic dogs with normal hepatic functions can have their urea serum level low because of low intake of proteins; nevertheless, a rise in the plasmatic urea is not exceptional. Dogs suffering from some affection to the functionality of liver parenchyma have normal serum urea levels if they are at the same time dehydrated or their kidney functions are impaired. Decreased production of urea is one of the causes of polyuria owing to the drop in the osmotic gradient in the kidney cortex (Dial 1995).

Serum cholesterol levels are variable in diseases of the liver. Cholesterol is excreted from the organism primarily through the biliary system and its rise is usually associated with diseases of this system. Hypocholesterolemia is associated with a long-lasting liver disease. The reason for this is the drop in the production or absorption from the intestines or higher conversion to bile acids. The most frequent liver disorder associated with hypocholesterolemia is the portosystemic shunt, in which increased conversion to bile acids is the primary mechanism (Leveille-Webster 2000).

The liver is the source of most proteins taking part in the blood coagulation (fibrinogen, 
prothrombin, factors V, VII, IX, X, XI, and XII together with factors II, VII, IX and X, which are K-vitamin dependent) and blood coagulation inhibitors (antithrombin III, plasminogen, $\alpha_{2}$-macroglobulin, $\alpha_{2}$-antiplasmin) (Feldman 1980). Contrary to human medicine blood coagulation tests are only used to a limited extent for the monitoring of hepatic functions.

\section{Cytology of the blood}

There are changes in the blood differential count in diseases of the liver. Morphological changes of erythrocytes associated with the liver diseases include microcytosis, acanthocytosis, schistocytes and Heinz bodies (Leveille-Webster 2000). Most inflammatory diseases of the organism are associated with leukocytosis; septic cases, on the other hand, are accompanied by leukopenia. Bacterial infections cause neutrophilia with a left-shift and a higher proportion of toxic neutrophils as well as monocytes (Center 1998). For the examination of blood smears it is necessary to notice the prospective presence of developmental stages of parasites. In the mouse and rat we can find the protozoan Hepatozoon muris, which infects cells of the liver, spleen, bone marrow and leukocytes (Jelínek 1992).

Serology of the blood collected is used in a routine way in experimental laboratories for the purpose of health state screening. It is very precise and the centre of its use lies in the diagnostics of viral infections (Jelínek 1992; Jelínek et al. 1993; Gabrisch 1995; Pearson and Gorham 1998). These examinations are not routinely used in a common clinical practice dealing with small pet mammals.

\section{Invasive diagnostic procedures Biopsy and endoscopic examination}

Biopsy is a method aiding in the determination of a precise diagnosis and disease prognosis (Konrád 1989). Liver biopsy is indicated in cases of abnormal enzymatic activities associated with liver functions and their persistence for as long as 30 days and more, hepatomegaly of undetermined origin, liver complications of systemic diseases, suspected neoplasia, therapy response determination, disease progression (Hoefer 1992; Kerwin 1995). A common finding mentioned in association with histology of liver biopsies from small mammals is the liver steatosis. It is a result of general illness (obesity, fasting, infection, etc.) influencing the morphology of the liver and subsequently its physiological functions. Carlton and McGavin (1995) defined the liver steatosis as excessive accumulation of lipids in hepatocytes. The presence of fat in the liver does not have to be necessarily a pathologic finding. Intrahepatic lipid deposition is to some extent quite physiological. It is clear that the diagnostics of liver steatosis is not only based on the determination of lipids in the liver tissue, but also on their precise localisation and quantification. In small mammals we can utilise most of the methods used in the cat and dog. Following methods can be considered in small mammals: fine-needle aspiration biopsy, percutaneous biopsy, biopsy under the guidance of ultrasonography, biopsy under endoscopic / otoscopic guidance, biopsy at the time of exploratory laparotomy.

\section{Fine-needle aspiration biopsy}

The method is suitable for the cytology of the liver tissue. If there are diffuse processes affecting the liver tissue (steatosis, steroid-induced hepatopathy, diffuse neoplasia), this method has a high diagnostic value (Rebar 1989b). The animal is positioned in the right lateral recumbency for the sampling. The needle is inserted through a spot caudal to cartilago xiphoidea, it goes along the rib arch at a 45-degree angle to the diaphragm. The 
probability of liver tissue penetration rises in animals suffering from hepatomegaly. There are minimum equipment requirements $(22-25 \mathrm{G}$ needles, $5-10 \mathrm{ml}$ syringes and slides for the smear) (Rebar 1989c). Complications in patients the size of a dog are relatively infrequent (Teske 1998). There can be bleeding in serious cases of coagulopathies (anticoagulant-agent intoxications, disseminated intravascular coagulation) or injury to large vessels. We have encountered this problem in our practice. It is therefore necessary to check the patient 12 and 24 hours after the procedure. Sampling other tissues is yet another complication. Small mammals have always to be sedated.

Table 4

Cytology and biochemical indices of blood in small mammals (Knotková and Knotek 2000)

\begin{tabular}{|c|c|c|c|c|c|c|c|}
\hline Values & Units & Hamster & Mouse & Rat & Chinchilla & Rabbit & Guinea pig \\
\hline Erythrocytes & $\mathrm{T} / 1$ & $5-9.2$ & $7.9-10.1$ & $5.4-8.5$ & $6.6-10.7$ & $5.1-7.9$ & $3.2-8.0$ \\
\hline Haemoglobin & $\mathrm{g} / 1$ & $146-200$ & $110-145$ & $115-160$ & $117-135$ & $100-174$ & $100-172$ \\
\hline Haematocrit & $\mathrm{l} / 1$ & $0.46-0.52$ & $0.37-0.46$ & $0.37-0.49$ & 0.38 & $0.33-0.50$ & $0.32-0.50$ \\
\hline Leukocytes & $\mathrm{G} / 1$ & $5-10$ & $5-13.7$ & $4-10.2$ & $7.6-11.5$ & $5.2-12.5$ & $5.5-17.5$ \\
\hline Neutrophils & $\mathrm{G} / 1$ & $1.5-3.5$ & $0.4-2.7$ & $1.3-3.6$ & $0.7-6.0$ & $0.6-9.9$ & $1.1-4.0$ \\
\hline Lymphocytes & $\mathrm{G} / 1$ & $6.1-7$ & $7.1-9.5$ & $5.6-8.3$ & $1.6-6.8$ & $2.6-11.2$ & $2.1-7$ \\
\hline Monocytes & $\mathrm{G} / 1$ & $0-1.0$ & $0-0.9$ & $0-0.6$ & $0-0.4$ & $0-0.9$ & $0-0.5$ \\
\hline Eosinophils & $\mathrm{G} / 1$ & $0-0.4$ & $0-0.5$ & $0-0.7$ & $0-0.7$ & $0-0.2$ & $0-0.4$ \\
\hline Basophils & $\mathrm{G} / 1$ & $0-0.1$ & $0-0.1$ & $0-0.1$ & $0-0.1$ & $0-0.7$ & $0-0.3$ \\
\hline TP & $\mathrm{g} / 1$ & $64-73$ & $42-60$ & $63-86$ & $50-60$ & $54-83$ & $42-68$ \\
\hline Albumin & $\mathrm{g} / 1$ & $32-37$ & $21-34$ & $33-49$ & $25-42$ & $24-46$ & $21-39$ \\
\hline Globulin & $\mathrm{g} / 1$ & $27-42$ & $18-82$ & $24-39$ & $18-25$ & $15-28$ & $17-26$ \\
\hline Glucose & $\mathrm{mmol} / 1$ & $3.60-4.05$ & $9.66-18.59$ & $4.72-7.33$ & $3.33-6.66$ & $4.16-8.60$ & $3.33-6.94$ \\
\hline Urea & $\mathrm{mmol} / 1$ & $6.99-9.99$ & $5.66-9.66$ & $5.33-8.99$ & $1.67-4.16$ & $2.16-4.83$ & $1.50-5.25$ \\
\hline Creatinine & $\mathrm{mmol} / 1$ & $53-89$ & $26.5-61.8$ & $17.5-70.8$ & None & $44.2-221$ & $53.0-194.5$ \\
\hline Cholesterol & $\mu \mathrm{mol} / 1$ & $4.71-6.14$ & $1.27-2.49$ & $1.19-2.38$ & $1.04-2.59$ & $0.26-2.07$ & $0.41-1.11$ \\
\hline AST & $\mu \mathrm{kat} / 1$ & $0.88-2.07$ & $0.92-4.18$ & $0.65-1.53$ & $0.25-0.75$ & $0.23-1.88$ & $0.43-1.13$ \\
\hline ALT & $\mu \mathrm{kat} / 1$ & $0.35-0.83$ & $0.47-3.07$ & $0.28-0.83$ & $0.17-0.58$ & $0.80-1.33$ & $0.42-0.98$ \\
\hline ALP & $\mu \mathrm{kat} / 1$ & $0.13-0.30$ & $0.47-1.57$ & $0.65-3.60$ & $0.05-0.20$ & $0.07-0.27$ & $0.92-1.80$ \\
\hline
\end{tabular}

\section{Percutaneous biopsy}

This technique is common in veterinary medicine. Indications for the use of this technique are the same as in the fine-needle aspiration biopsy (diffuse processes). Special biopsy needles are used (Tru-Cut system, gun system, Kerwin 1995). Contrary to the fineneedle aspiration biopsy, using this method we obtain larger samples providing enough material both for the cytology and histology which enhances the precision of the diagnosis up to 80 to $90 \%$ (Hardy 1990). The patient requires general anaesthesia for the prevention of whatever movements. The animal is restrained in dorsal recumbency with 30 to $45 \%$ rotation to the right. This position minimises the risk of injury to the gall bladder and subsequent peritonitis. There is no such danger in the rat having no gall bladder (Pope sko et al. 1990b). The area outlined by cartilago xiphoidea, the left rib arch and umbilicus is clipped and surgically prepared. Strict aseptic measures are essential (Hitt et al. 1992). The needle is inserted so as to pass through the abdominal wall and then the biopsy cannula goes 
1 to $2 \mathrm{~cm}$ deep (depending on the size of the animal). There was described a variation to this method called "key-hole" in the dog and cat. The first thing to do using this method is to make a small incision through the abdominal wall. It is advantageous that the cannula is then inserted directly into the liver tissue (Day 2000). This modification can be quite successfully utilised in small mammals. The surgeon is able to stabilise the liver lobe when inserting the needle. Complications of these techniques include: inadequate sedation of the patient and movement of the patient during sampling, inadequate reaction of the patient on sedation or anaesthesia, bleeding, presence of greater quantity of gall in the sample, contamination by puss following abscess puncture, sampling other tissue, shock after sampling (Kerwin 1995).

There is a danger of injury to the diaphragm and thoracic cavity organs or large vessels and bleeding in patients the size of a mouse. We, therefore, recommend checking the patient during 12 to 24 hours after the procedure. Regarding the above-mentioned hazards, in our experience it is better to use other safer methods for the sampling (biopsy under endoscopic guidance, biopsy using an otoscope for the guidance, biopsy during laparotomy). These methods considerably reduce the risk of injuring the patient during sampling.

\section{Biopsy under ultrasonographic guidance}

Examination using ultrasonography before the biopsy provides information on the hepatic tissue state, identification of focal lesions (neoplasia, cysts, abscesses) or even general changes of the liver (fibrosis, steatosis). The method allows to control the movement of the biopsy needle and thus gives precision to the sampling (Léveillé et al. 1993). The patient has to be deep sedated or is given general anaesthesia. The area of insertion of the biopsy needle is prepared in a similar way as it is explained for the percutaneous biopsy. Complications are less prevalent owing to the visualisation of sampling. We employ this method practically in small mammals the size of a rabbit or a ferret.

\section{Biopsy under endoscopic guidance}

Endoscopy is the procedure suitable for the exact evaluation of liver surface and guided sampling for the cytology and histology. It requires instrumentation and experience of the practitioner with surgical procedures in small mammals. As diagnostic biopsies are taken mainly from patients suffering from suspected hepatopathies, it is necessary to select a safe and reliable system of general anaesthesia which influences the liver and kidney functions to a minimum extent. Inhalation anaesthesia using isoflurane is the most suitable system in this respect. Endoscopy is the least invasive method because there is no need for a large incision to visualise the liver tissue in situ. It provides the possibility to take a biopsy specimen directly from the affected liver part, focal lesions or diffuse changes (Jones 1989). It is a good alternative to laparotomy. The veterinary surgeon is able to evaluate the state of other organs such as the gall bladder, small and large intestines, pancreas at the same time (Twedt 1999). Linea alba (Meredith and Rayment 2000) is the most commonly selected laparotomy access line in small mammals. The patient is restrained in dorsal recumbency and the area of entry is prepared for a surgical incision. Abdominal cavity insufflation is recommended for the procedure. The examination is contra-indicated in patients in which the disease can be surgically solved through laparotomy or in animals in danger of life. Expensive instrumentation, longer duration of the procedure and thus higher load to the patient are the disadvantages of this diagnostic approach (Day 2000). The pressure of the insufflated gas can decrease the minute respiratory volume; assisted ventilation using the breathing bag is therefore essential (Kerwin 1995). 
Bunch et al. (1985) described a procedure using a sterile otoscope instead of an endoscope. We are employing this modification successfully in small mammals.

\section{Biopsy during exploratory laparotomy}

Exploratory laparotomy is indicated in cases of diseases which have to be surgically treated, in extra-hepatic biliary tract obstructions, and neoplasia affecting only one liver lobe. The advantages of this method without any doubt include direct visualisation of all organs in the abdomen and the possibility to obtain samples from a number of organs (lymph nodes can be sampled in suspected cases of neoplasia) and immediate surgical treatment (D ay 2000). The method is associated with a considerable load of the patient (it is essential that the patient be clinically evaluated and the hazards of the procedure considered). The biopsy specimen can be sampled using a punch biopsy technique, partial lobectomy and a ligature (Kerwin 1995).

Table 5

Methods of liver parenchyma examination and their utilisation in the clinical practice engaged with small mammals

\begin{tabular}{|c|c|c|c|c|c|c|c|}
\hline \multirow{2}{*}{ Methods } & \multicolumn{7}{|c|}{ Utilisation in small mammals } \\
\hline & Ferret & Hamster & Mouse & Rat & Chinchilla & Rabbit & Guinea pig \\
\hline Liver palpation & Yes & Limited & No & Limited & Yes & Yes & Limited \\
\hline Blood sampling & Yes & Limited & Limited & Limited & Yes & Yes & Limited \\
\hline Abdominocentesis & Yes & Yes & Yes & Yes & Yes & Yes & Yes \\
\hline Coprology & Yes & Yes & Yes & Yes & Yes & Yes & Yes \\
\hline $\begin{array}{l}\text { Radiographic } \\
\text { examination }\end{array}$ & Yes & Yes & Limited & Yes & Yes & Yes & Yes \\
\hline Ultrasonography & Yes & No & No & Limited & Limited & Yes & Limited \\
\hline $\begin{array}{l}\text { Computer } \\
\text { tomography }\end{array}$ & \multicolumn{7}{|c|}{ Non-utilisable } \\
\hline Scintigraphy & \multicolumn{7}{|c|}{ Non-utilisable } \\
\hline Magnetic resonance & \multicolumn{7}{|c|}{ Inaccessible but utilisable } \\
\hline $\begin{array}{c}\text { Fine-needle } \\
\text { aspiration biopsy }\end{array}$ & Yes & Limited & Limited & Limited & Limited & Yes & Limited \\
\hline Percutaneous biopsy & Yes & Limited & No & Limited & Limited & Yes & Limited \\
\hline Endoscopic biopsy & Yes & Yes & Limited & Yes & Yes & Yes & Yes \\
\hline Laparotomy & Yes & Yes & Yes & Yes & Yes & Yes & Yes \\
\hline
\end{tabular}

\section{Utilisation of the above-mentioned methods in minute mammals}

Without any problems, we used the above-mentioned methods in the diagnostics of hepatopathies in rabbits, ferrets, adult guinea pigs and rats (Table 5). On the other hand, utilisation of these methods in hamsters, Djungarian hamsters or mice is rather questionable, but possible. History and clinical examination often lead the veterinarian to consider a liver damage. Radiography reveals liver enlargement and prospective masses. It is, however, considerably limited by the size of the patient. This limitation concerns also ultrasonography. It must be admitted that computer tomography, magnetic resonance and scintigraphy belong to progressive methods which find their way to utilisation in the veterinary medicine, their use in small mammals is, however, still limited. Examinations of 
abdominal effusions and coprology are much more efficient. There are problems with blood collection and subsequent haematology and biochemistry owing to insufficient blood volume. Liver biopsy sampling can be a life-threatening procedure requiring experience and care. This procedure, nevertheless, provides enough information on the current state of the liver parenchyma. In our experience and practice, the described modifications of liver biopsy are essential in the diagnostics of hepatopathies in small mammals.

\section{Posouzení významu jednotlivých metod klinické diagnostiky hepatopatií u drobných savců}

Možnosti intravitálního průkazu narušené funkce jater u drobných savců jsou doposud využívány minimálně. Přitom je nutnost včasné diagnostiky hepatopatií u těchto pacientů aktuální. Předkládaná práce shrnuje diagnostické postupy a je zaměřena na posouzení jejich praktického využití u drobných savců. Nezastupitelnou roli hraje posouzení anamnestických dat a důkladné palpační vyšetření jater s odběrem tekutiny $\mathrm{z}$ dutiny břišní za účelem laboratorní analýzy. Analýza biochemických parametrů krve zahrnuje sledování enzymů indikujících hepatocelulární poškození (ALT, AST, LDH), cholestazu nebo alteraci aktivit enzymů (ALP, GMT), parametrů monitorujících jaterní syntézu (albumin, glukóza, urea, koagulační faktory), úroveň konjugace a sekrece (bilirubin a žlučové kyseliny) a tzv. portal clearens (žlučové kyseliny, amoniak). Při potvrzení ascitu v dutině břišní je důležité bližší určení jeho charakteru. Přesné posouzení stavu jater umožňují cytologická a histologická vyšetření bioptátů. Pro drobné savce velikosti králíka, fretky, dospělého morčete a potkana jsou vhodnými metodami jaterních biopsií: aspirační tenkojehelná, perkutánní, pod kontrolou ultrasonografu, pod kontrolou endoskopu nebo otoskopu a biopsie při probatorní laparotomii. U pacientů velikosti křečka, křečíka džungarského nebo myši je indikace těchto metod diskutabilní, nebot představují vážné riziko ohrožení života. Přesto mají uvedené modifikace biopsií jater při diagnostice hepatopatií drobných savců rozhodující význam.

\section{Acknowledgements}

This paper originated as a part of the research project of the Ministry of Education, Youth and Physical Education of the Czech Republic (No. 161/700002). Authors wish to thank Dagmar Karešová, Vladimír Jekl and Roman Šebesta for their technical assistance in the anaesthesia of patients, biological material sampling and small animal breeding.

\section{References}

ANDERSON, N.V. 1992: Excessive fluid in abdomen: effusions. In: ANDERSON, N.V.: Veterinary gastroenterology. Lea and Febiger, London, pp. 382-388

ANGULO, P., PEARCE, D.H., JOHNSON, C.D., HENRY, J J., LARUSSO, N.F, PETERSEN, B T , LINDOR, K.D. 2000: Magnetic resonance cholangiography in patients with biliary disease: its role in primary sclerosing cholangitis. J. Hepatol. 33: 520-527

BOOTHE, H.W., BOOTHE, D.M. KOMKOV, A., HIGHTOWER, D. 1992: Use of hepatobiliary scintigraphy in the diagnosis of extrahepatic biliary obstruction in dog and cats: 25 cases (1982 - 1989). J. Am. Vet. Med. Assoc. 201: $134-141$

BROWN, S.A. 1992: Basic anatomy, physiology, and husbandry. In: HILLYER, E.V. QUESENBERRY, K.E.: Ferrets, rabbits, and rodents clinical medicine and surgery. W.B. Saunders, Philadelphia, pp. 3-13

BUNCH, S.E. 1998a: Hepatobiliary and exocrine pancreatic disorders. In: NELSON, R.W., COUTO, C.G.: Small animal internal medicine. $2^{\text {th }}$ ed. Mosby, St. Louis, pp. 475-570

BUNCH, S.E. 1998b: Scintigraphy. In: NELSON, R.W., COUTO, C.G.: Small Animal Internal Medicine. Mosby, Inc., Missouri, pp. 501-502

BUNCH, S.E., POLAK D.M., HORBUCKLE W.E. 1985: A modified laparoscopic approach for liver biopsy in dogs. J. Am. Vet. Med. Assoc. 187: 1032-1035

CARLTON, W.W., MCGAVIN, M.D. 1995: Thompson's special veterinary pathology. Mosby, St Louis, pp. 88 - 89

CENTER, S.A. 1993: Disorders of the hepatobiliary system. In: WILLS, J., WOLF, A.: Handbook of feline medicine. Pergamon Press, Oxford, pp. 175-192 
CENTER, S.A. 1998: Hepatobiliary infections. In: GREENE, C.E.: Infectious diseases of the dog and cat. $2^{\text {th }}$ ed. W.B. Saunders, Philadelphia, pp. 615-625

CENTER, S.A., BALDWIN, B.H., HOLLIS, N.E., TENNANT, B.C. 1985: Bile acid concentration in the diagnosis of hepatobiliary disease in the dog. J. Am. Vet. Med. Assoc. 187: 935-940

CENTER, S.A., BALDWIN, B.H., HOLLIS, N.E., TENNANT, B.C. 1986: Bile acid concentration in the diagnosis of hepatobiliary disease in the cat. J. Am. Vet. Med. Assoc. 189: 891-896

CENTER, S.A., SLATER, M.R., MANWARREN, T., PRYMAK, K. 1992: Diagnostic efficacy of serum alcaline phosphatase and -glutamyltransferase in dogs with histologically confirmed hepatobiliary disease: 270 cases (1980 - 1990). J. Am. Vet. Med. Assoc. 201: 1258-1264

CLARENBURG, R. 1992a: Lipid metabolism. In: CLARENBURG, R.: Physiological chemistry of domestic animals. Mosby-Year Book, Inc., St. Louis, pp. 292-333

CLARENBURG, R. 1992b: Gastrointestinal functions. In: CLARENBURG, R.: Physiological chemistry of domestic animals. Mosby-Year Book, Inc., St. Louis, pp. 203-217

DAY D.G. 2000: Indications and techniques for liver biopsy. In: ETTINGER, S.J., FELDMAN, E.C.: Textbook of veterinary internal medicine. $5^{\text {th }}$ ed. Vol 2, W.B. Saunders, Philadelphia, pp. 1294-1298

DIAL, S.M. 1995: Clinicopathologic evaluation of the liver. Vet. Clin. North Am. Small Anim. Pract. 25: 257-273

DIVERS, S.J., COOPER, J.E. 2000: Hepatic lipidosis. Seminars in Avian and Exotic Pet Medicine. 9: 153-164

DONELLY, T.M. 1997: Disease problems of small rodents. In: HILLYER, E.V., QUESENBERRY, K.E.: Ferrets, rabbits, and rodents - clinical medicine and surgery. W.B. Saunders, Philadelphia, pp. 307-327

EGEN, H., ERNST, H. 1995: Chinchilla. In: GABRISCH, K., ZWART, P.: Krankheiten der Heimtiere. $3^{\text {th }}$ ed. Schlütersche, Hannover, pp. 173-196

FELDMAN, B.F. 1980: Clinical Pathology of the Liver. In: KIRK, R.W. et al.: Current veterinary therapy VII. W.B. Saunders, Philadelphia, pp. 875-885

GABRISCH, K. 1995: Frettchen und Marder. In: GABRISCH, K., ZWART, P.: Krankheiten der Heimtiere. $3^{\text {th }}$ ed. Schlütersche, Hannover, pp. 235-274

GIEBLER, D. 1995: Hörnchen. In: GABRISCH, K., ZWART, P.: Krankheiten der Heimtiere. $3^{\text {th }}$ ed. Schlütersche. Hannover, pp. 217-233

GREENE, C.E. 1998: Salmonellosis. In: GREENE, C.E.: Infectious diseases of the dog and cat. $2^{\text {th }}$ ed. W.B. Saunders, Philadelphia, pp. $235-240$

HARDY, H. 1990: The percutaneous approach. Vet. Med. Rep. 2: 192-194

HITT, M.E., HANNA, P., SINGH, A. 1992: Percutaneous transabdominal hepatic needle biopsies in dogs. Am. J. Vet. Res. 53: 785-787

HOEFER H.L. 1992: Liver disease. In: HILLYER, E.V. QUESENBERRY, K.E.: Ferrets, rabbits, and rodents clinical medicine and surgery. W.B. Saunders, Philadelphia, pp. 32-33

HOUSE, J.K., SMITH, B.P., VANMETRE, D.C., FECTEAU, G.,CRAYCHEE, T., NEVES, J. 1992: Ancillary tests for assessment of the ruminant digestive system. Vet. Clin. North Am. Food Anim. Pract. 8: 203-232

HUBNER, G.H., STEUDEL, N., KLEBER, G., BEHRMANN, C., LOTTERER, E., FLEIG, W.E. 2000: Hepatic arterial blood flow velocities: assessment by transcutaneous and intravascular Doppler sonography. J. Hepatol. 32: $893-899$

JELÍNEK, F. 1992: Játra a vývodní cesty žlučové. In: JELÍNEK, F.: Úvod do patologie laboratorních zvířat. Stanislav Hojek, Praha, pp. 77-95

JELÍNEK, F., ALDOVÁ, E., LÁVIČKOVÁ, M., ŠKARDOVÁ, O., ZAJÍČEK, D. 1993: Nemoci laboratorních zvířat. VŠVF, Brno, $120 \mathrm{p}$.

JERGENS A.E. 1997: Gastrointestinal disease and its management. Vet. Clin. North Am. Small Anim. Pract. 27: 1373-1402

JONES, B.D. 1989: The use of laparoscopy to obtain liver biopsies. In: AAHAęs $56^{\text {th }}$ Annual meeting proceedings, 7. 14. 5. 1989, St. Louis, pp. 149-150

KAYA, M., ANGULO, P., LINDOR, K.D. 2000: Overlap of autoimmune hepatitis and primary sclerosing cholangitis: an evaluation of a modified scoring system. J. Hepatol. 33: 537-542

KELNER, P. 1999a: Počítačová tomografie. In: KELNER, P. a kol.: Vnitřní lékařství: Zobrazovací metody. Karolinum, Praha, p. 526

KELNER, P. 1999b: Magnetická rezonance. In: KELNER, P. a kol.: Vnitřní lékařství: Zobrazovací metody. Karolinum, Praha, p. 527

KERWIN, S.C. 1995: Hepatic aspiration and biopsy techniques. Vet. Clin. North Am. Small Anim. Pract. 25: $275-$ 291

KLIMEŠ, J. 1997: Laboratorní diagnostika onemocnění jater. Sborník referátů Klinická interpretace laboratorních vyšetření u psa a kočky, ČAVLMZ, Hradec Králové, pp. 16-20

KNOTEK, Z. 1999: Infekční peritonitida koček. In: SVOBODA, M., POSPÍŠIL, Z. et al.: Infekční nemoci psa a kočky, ČAVLMZ,Brno, pp. 196-210

KNOTKOVÁ, Z., KNOTEK, Z., 2000: Fyziologické hodnoty u drobných savců. Noviko, Brno, 69 p.

KONRÁD, J. 1989: Intravitální punkce (biopsie) jater. In: KONRÁD, J.: Nemoci kožešinových zvířat. SZN, Praha, pp. $45-46$ 
LÉVEILLÉ, R., PARTINGTON, B.P., BILLER, D.S., MIYABAYSHI, T. 1993: Complication after ultrasound guided biopsy of abdominal structures in dogs and cats: 246 cases (1984 - 1991). J. Am. Vet. Med. Assoc. 203: 413-415

LEVEILLE-WEBSTER, C.R. 2000: Laboratory diagnosis of hepatobiliary diseases. In: ETTINGER, S.J., FELDMAN, E.C.: Textbook of veterinary internal medicine. $5^{\text {th }}$ ed. Vol 2. W.B. Saunders, Philadelphia, pp. 1277-293

LOFSTED, J., KOBLIK, D., JAKOWSKI, R.M., McMILLAN, M.C., ENGELKING, L.R. 1988: Use of hepatobiliary scintigraphy to diagnose bile duct atresia a lamb. J. Am. Vet. Med. Assoc. 193: 95-98

LORENZ, M.D., CORNELIUS, L.M. 1992: Abdominal distention. In: LORENZ, M.D. CORNELIUS, L.M.: Small animal medical diagnosis. J.B. Lippincott, Philadelphia, pp. 73-77

MEREDITH, A., RAYMENT, L. 2000: Liver disease in rabbits. Seminars Avian and Exotic Pet Medicine. 9: 146152

MILES, K. 1997: Imaging abdominal masess. Vet. Clin. North Am. Small Anim. Pract. 27: 1403-1431

NAPIER, R.A.N. 1969: Králíci. In: LANE-PETTER W.: Laboratorní zví̌ata. ACADEMIA, Praha, pp. 425- 471

PEARSON, R.C., GORHAM, J.R. 1998: Viral disease models. In: FOX, J.G.: Biology and diseases of the ferret. $2^{\text {th }}$ ed. Williams a Wilkins, Baltimore, pp. 487-497

PERMAN, V. 1989: Examination of the inflammatory exudate. In: AAHA's $56^{\text {th }}$ Annual meeting proceedings, 7. 14. 5. 1989, St. Louis, pp. 154-157

POPESKO, P., RAITOVÂ, V., HORÁK, J. 1990a: Atlas anatómie malých laboratornych zvierat 1. Príroda, Bratislava, $256 \mathrm{p}$.

POPESKO, P., RAITOVÁ, V., HORÁK, J. 1990b: Atlas anatómie malých laboratornych zvierat 2. Príroda, Bratislava, $253 \mathrm{p}$.

REBAR, A.H. 1989a: Evaluation of pleural, peritoneal, and pericardial effusions. In: AAHA's $56^{\text {th }}$ Annual meeting proceedings, 7. 14. 5. 1989, St. Louis, pp. 162-168

REBAR, A.H. 1989b: Diagnostic cytology as an aid to the evaluation of hepatic disease. In: AAHA's $56^{\text {th }}$ Annual meeting proceedings, 7. 14. 5. 1989, St. Louis, pp. 169-171

REBAR, A.H. 1989c: Diagnostic cytology I: Collection techniques. In: AAHA's $56^{\text {th }}$ Annual meeting proceedings, 7. 14. 5. 1989, St. Louis, pp. 151-153

ROTHUIZEN, J., MEYER, H.P. 2000: History, physical examination, and signs of liver disease. In: ETTINGER, S.J., FELDMAN, E.C.: Textbook of veterinary internal medicine. $5^{\text {th }}$ ed. Vol. 2. W.B. Saunders, Philadelphia, pp. 1272-1277

ROTHUIZEN, J., Van den BROM, W.E. 1990: Quantitative scintigraphy as a measure of bile flow in dogs with cholestatic disease. Am. J. Vet. Res. 51: 253-256

SCHALL, H. 1995: Kaninchen. In: GABRISCH, K., ZWART, P.: Krankheiten der Heimtiere. $3^{\text {th }}$ ed. Schlütersche, Hannover, 3.ed., pp. 1-45

SEVELIUS, E. ANDERSSON, M. 1995: Serum protein electrophoresis as a prognostic marker of chronic liver disease in dogs. Vet. Rec. 137: 663-667

SPARKES, A., GRUFFYDD-JONES, T.J. 1993: Laboratory diagnostic aids. In: WILLS, J., WOLF, A.: Handbook of feline medicine. Pergamon Press, Oxford, pp. 91-112

TESKE, E. 1998: Klinická cytologie v medicíně zviřat chovaných ze záliby. In: Sborník 6. konference ČAVLMZ, Onkologie malých zvírat, 17 - 18.10.1998, pp. 31-35

TWEDT, D.C. 1999: Laparoscopy of the liver and pancreas. In: TAMS, T.R.: Small animal endoscopy. Mosby, St. Luis, pp. 409-418

YEAGER, A.E. 1992: Accuracy of ultrasonography in the detection of severe hepatic lipidosis in cats. Am. J. Vet. Res. 53: 597-599 


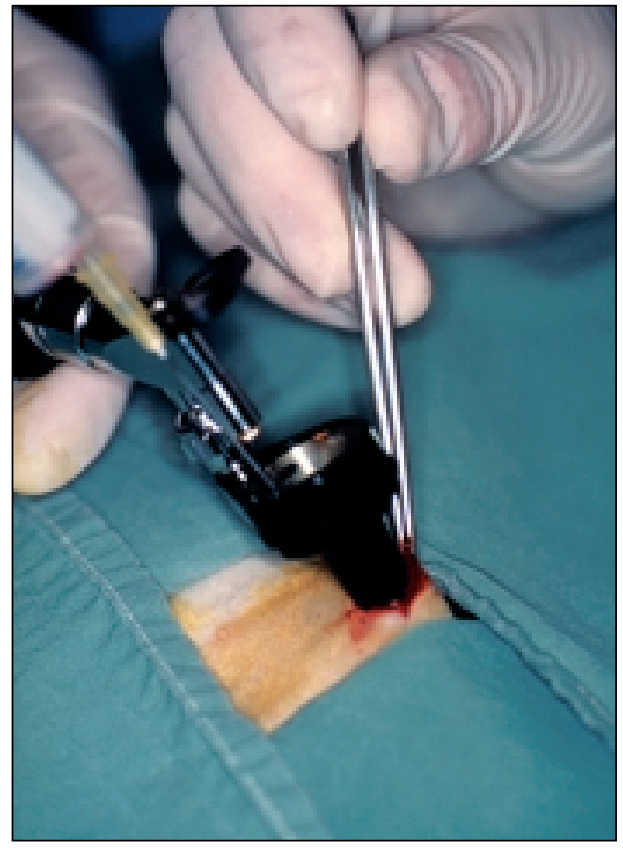

Fig. 1. Fine-needle aspiration biopsy under the otoscopic guidance (rat).

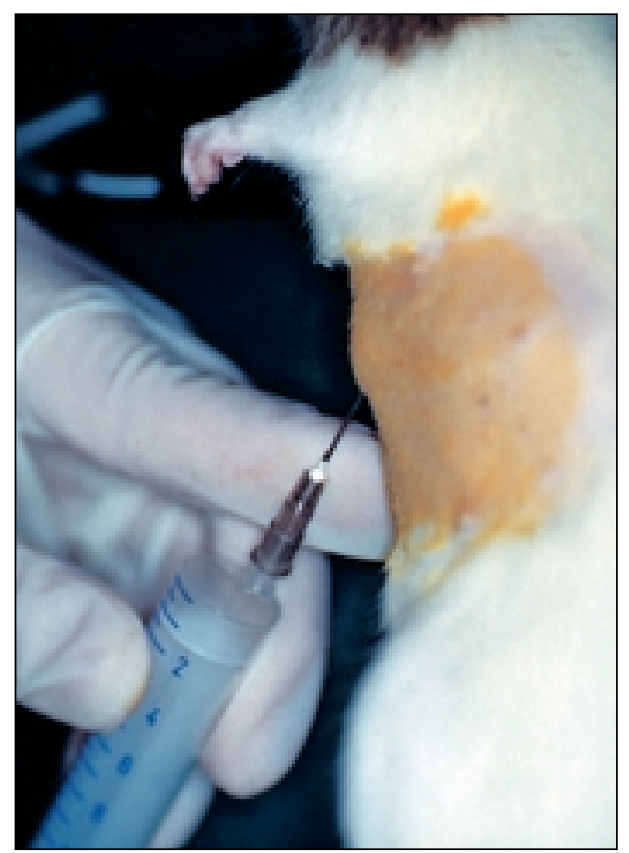

Fig. 3. Percutaneous biopsy (rat).

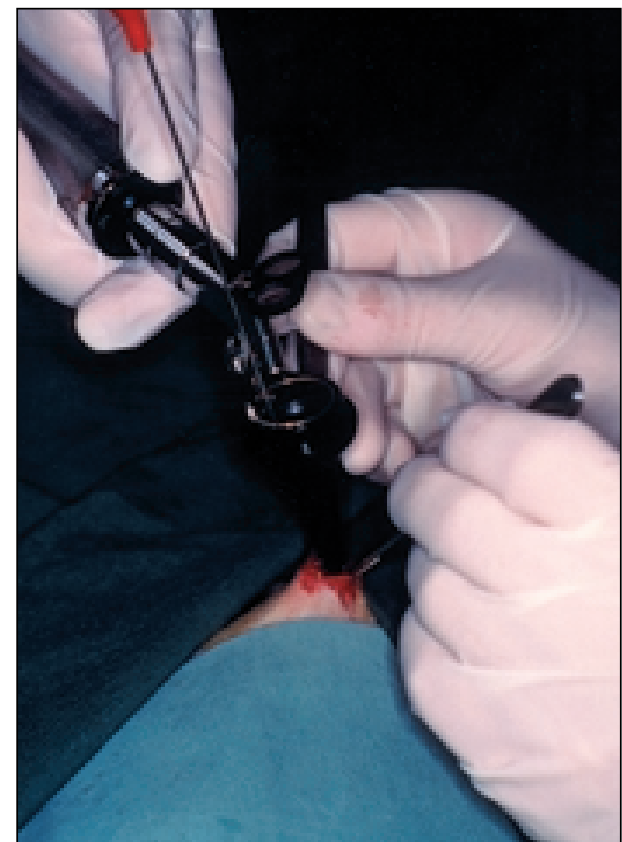

Fig. 2. Biopsy using a special biopsy needle under the otoscopic guidance (rat).

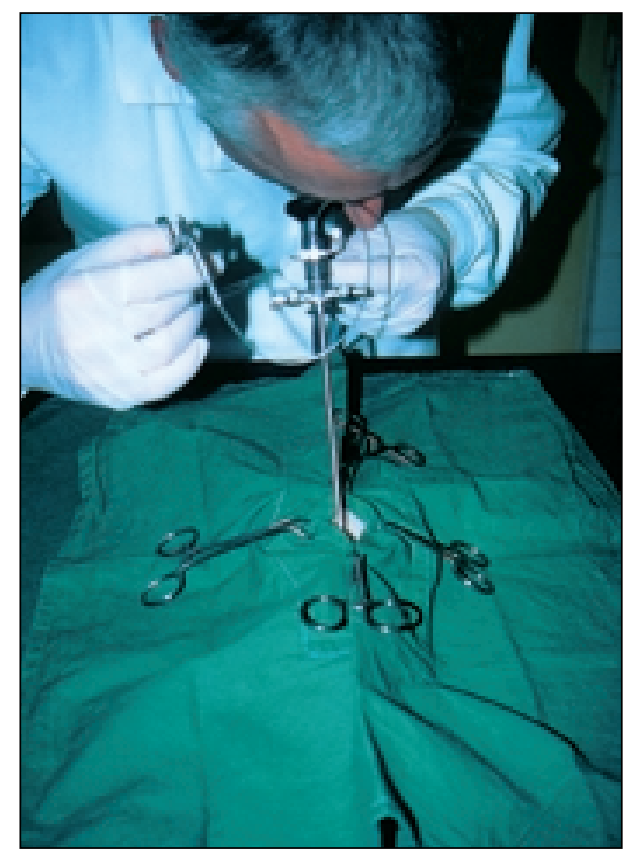

Fig. 4. Liver biopsy under the guidance of a rigid endoscope 


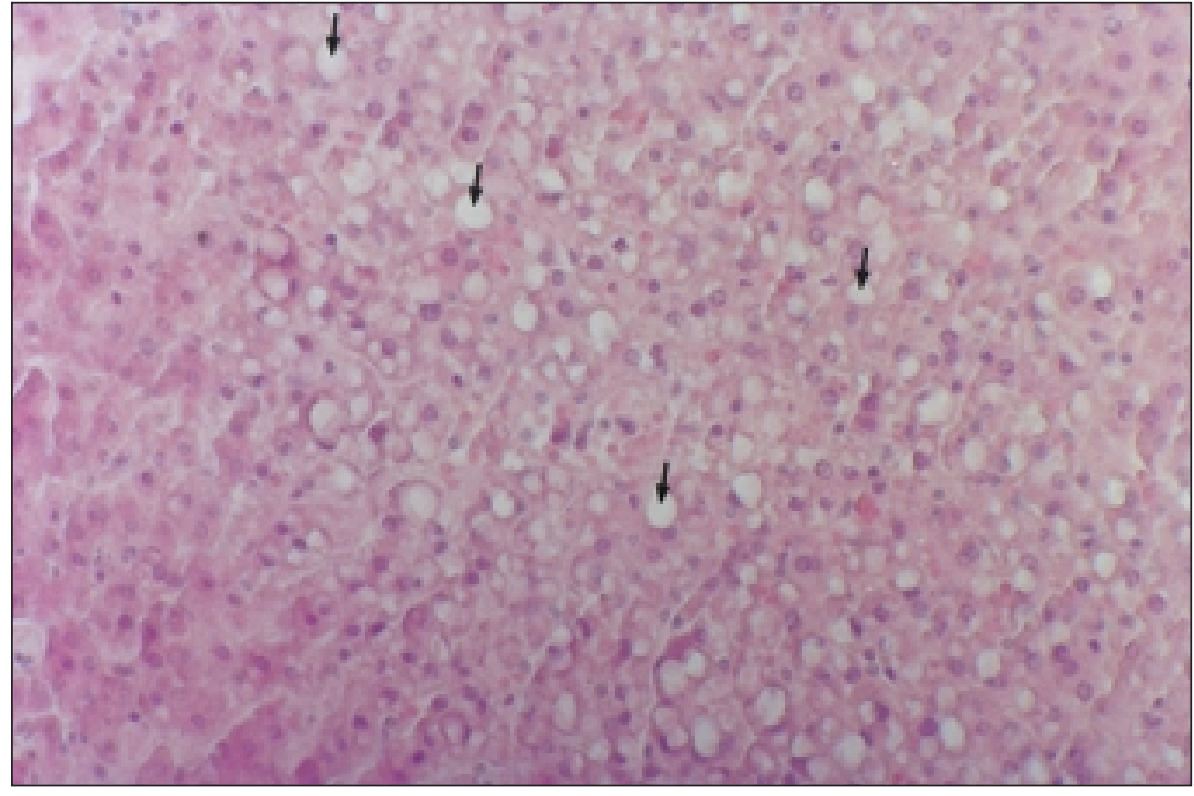

Fig. 5. A part of a hepatic tissue with large vacuole centrolobular steatous dystrophy. Lipid vacuoles $(\rightarrow)$. $\mathrm{HE}, \times 375$ (guinea pig).

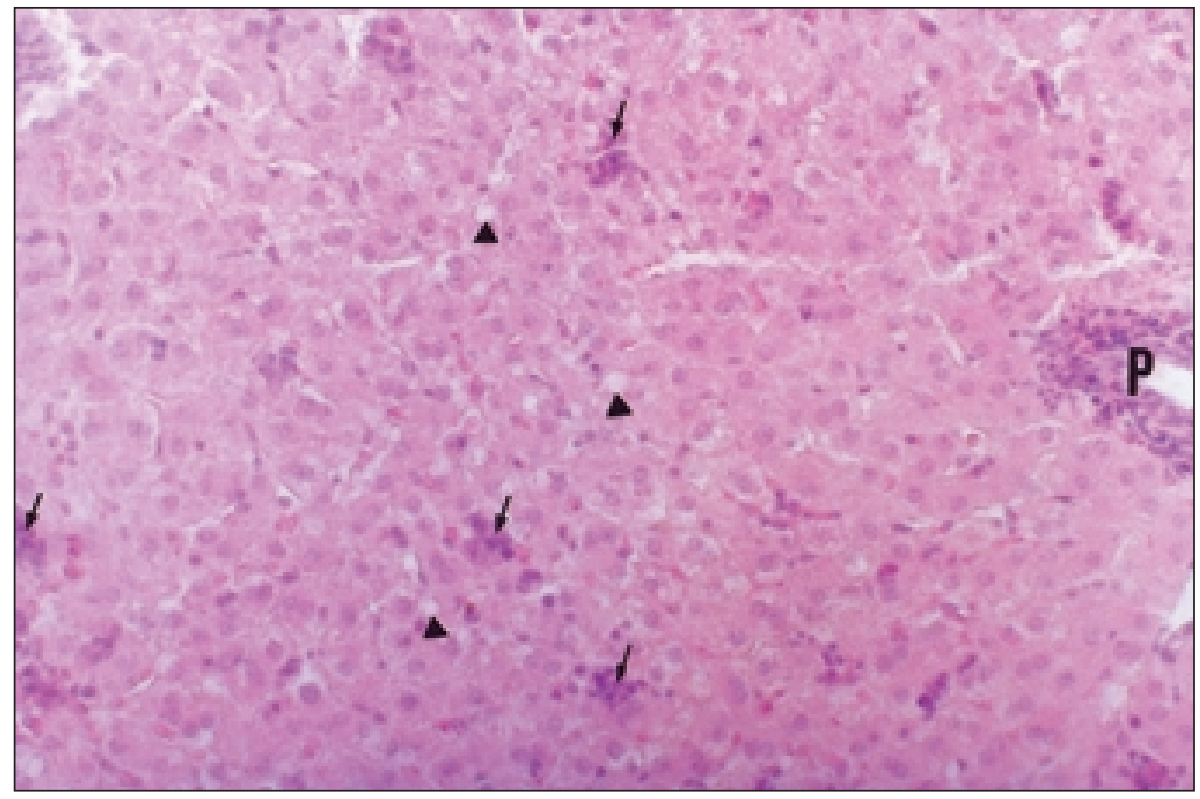

Fig. 6. Hepatitis with foci of infiltration between liver trabeculae $(\rightarrow)$ and periportal spaces $(\mathrm{P})$. Disseminated steatous dystrophy of hepatocytes $(\boldsymbol{\Delta})$. HE, $\times 375$ (chinchilla). 